\title{
PERKEMBANGAN EFISIENSI PENGGUNAAN MODAL KERJA DALAM MENGHASILKAN LABA PADA TARAWANGSA WOOD INSTRUMENT PERIODE 2010-2014
}

\section{DAHLIA}

\begin{abstract}
Financial or we can say working financial every company need working financial operations every day in order to fast, because of that company need to use the Working Capital Efficiency in order to be able to produce the optimal profit. So that the formulation of the problem in this research is how the developments in the Working Capital Usage Efficiency Produces Profit In Tarawangsa Wood Instrument period 2010-2014.

This research has the objective to determine developments in the Working Capital Efficiency Using Generate Profit On Wood Tarawangsa Wood Instruments. Current research variable Ratio, Return On Investment (ROI), Turnover Cash, Accounts Receivable Turnover, turnover Inventory
\end{abstract}

From the analysis above use of working capital from 2010-2014 tends to rise (more efficient) but is relatively slow, with the rate that is small efficiently too.

Keywords: Rentability, IEMK, Liquidity, Cash Turnover, Inventory Ratio, Cccounts Receivable Turnover

\section{PENDAHULUAN}

Melihat banyaknya pelaku usaha dan tenaga kerja yang terlibat dalam UMKM, maka pertumbuhan dan kemajuan UMKM sangat dibutuhkan dalam mendukung upaya mengatasi ketimpangan antar pelaku usaha, antar golongan pendapatan dan antar daerah termasuk penanggulangan kemiskinan. Terlepas dari besarnya peran UMKM bagi perkembangan perekonomian DIY, namun masih banyak permasalahan yang di hadapi UMKM salah satunya adalah keterbatasan modal kerja seta pengelolaannya, karena modal kerja merupakan faktor yang sangat penting bagi perusahaan.

Modal kerja juga sangat berpengaruh terhadap kelancaran kegiatan operasi perusahaan, oleh karena itu agar perusahaan dapat beroperasi dengan baik maka dibutuhkan pengelolahan modal kerja yang tepat. Pengelolaan modal kerja yang tepat sangat penting bagi perusahaan agar perusahaan dapat beroperasi secara efektif dan efisien, karena perusahaan pada dasarnya mempunyai tujuan jangka 


\section{JURNAL MANAJEMEN VOL. 5 NO. 2 DESEMBER 2015}

panjang dengan cara menghasilkan produk secara terus menerus agar memperoleh keuntungan yang optimum dari hasil penjualan produk. Untuk mencapai tujuan itu, perusahaan perlu memperhatikan tersedianya dana yang cukup jumlahnya untuk membiayai pengeluaranpengeluaran atau operasi perusahaan seperti membeli bahan mentah, membayar upah tenaga kerja, membayar utang jangka pendek, dan terhindar dari masalah

\section{KAJIAN PUSTAKA}

\section{Pengertian Efisiensi}

Menurut Akmaluddin Hasibuan (2012:27) mengatakan bahwa, efisiensi adalah tindakan meminimalkan biaya investasi dan eksploitasi untuk memaksimalkan pengunaan biaya

\section{Pengertian Modal Kerja}

Menurut Agnes Sawir (2005:129) mengatakan bahwa modal kerja adalah keseluruhan aktiva lancar yang dimiliki perusahaan, atau dapat pula dimaksudkan sebagai dana yang harus tersedia untuk membiayai kegitatan operasi perusahaan sehari-hari.

\section{Laba}

Menurut Kuswadi, (2007:131) megatakan bahwa laba adalah pendapatan dari hasil penjualan dikurangi dengan biaya-biaya pengadaan dan pemasaran.

\section{- Net Profit Magrin}

keuangan serta tidak mengalami kelebihan dan kekurangan modal kerja. Kelebihan modal kerja suatu perusahaan menyebabkan adanya dana yang tidak terpakai atau dana yang tidak produktif, dan sebaliknya jika perusahaan kekurangan modal kerja berarti jumlah dana yang tersedia tidak cukup untuk memenuhi kebutuhan perusahaan, yang dapat menganggu kegiatan perusahaan.

Menurut Hanafi (2013) rasio ini menghitung sejauh mana kemampuan perusahaan menghasilkan laba bersih pada tingkat penjualan terntentu

$$
\begin{aligned}
& \text { Net Profit Margin }= \\
& \frac{\text { EAT }}{\text { Net Sales }} \times 100 \%=\ldots \%
\end{aligned}
$$

\section{- Turnover Of Operating Asset}

Menurut Kasmir

(2013:185) mengatakan bahwa Total Asset turn over merupakan rasio yang digunakan untuk mengukur perputaran semua aktiva yang dimiliki perusahaan dan mengukur berapa jumlah penjualan yang diperoleh dari tiap rupiah aktiva.

Turnover Of Operating Asset $=$

$$
\frac{\text { Net Sales }}{\text { operating Asset (NOA) }}=\ldots \text { Kali }
$$

\section{- ROI}

Oleh karena rentabilitas ekonomi dipengaruhi oleh dua faktor yaitu profit margin dan turnover of operating asset 
maka ROI dapat dihitung dengan rumus sebagai berikut:

$\mathrm{ROI}=\mathrm{NPM} \times \mathrm{TOA}$

\section{- Curent Ratio}

Current Ratio menurut Sofyan Syafari Harahap (2002:301), mengatakan bahwa rasio ini menunjukan sejauh mana aktiva lancar menutupi kewajiban-kewajiban lancer, semakin besar perbandingan aktiva lancar dengan hutang lancar semakin tinggi kemampuan perusahaan menutupi kewajiban jangka pendeknya.

$$
\begin{gathered}
\text { Current Ratio }= \\
\frac{\text { Aktiva Lancar }}{\text { hutang Lancar }} \times 100 \%=\ldots \%
\end{gathered}
$$

\section{- Indeks Efisiensi Modal Kerja}

Indeks Efisiensi Modal Kerja (IEMK)merupakan perbandingan antara Rentabilitas dan Likuiditas, semakin tinggi Rentabilitas menunjukan efisiensi modal kerja semakin efisien, tetapi bila dipandang dari sudut pandang dari Likuiditas terlalu tinggi lebih tidak efisien (Mumpuni, 2013)

$$
I E M K=\frac{\text { Rentabilitas }}{\text { Likuiditas }}
$$

\section{- Perputaran Piutang}

Perputaran piutang merupakan rasio yang digunakan untuk mengukur berapa lama penagihan piutang selama satu periode atau berapa kali dana yang ditanamkan dalam piutang ini berputar dalam satu periode.

\section{- Perputaran Kas}

Rasio perputaran kas menunjukan seberapa cepat kas tersebut dapat kembali dalam satu periode

$$
\begin{gathered}
\text { perputaran } k a s=\frac{\text { penjualan }}{\text { Rata }- \text { rata Kas }} \\
=\cdots \text { kali }
\end{gathered}
$$

$$
\begin{gathered}
\text { Kas Rata }- \text { rata } \\
=\frac{\text { Kas Tahun Pertama }+ \text { Kas Tahun kedua }}{2}
\end{gathered}
$$

\section{Perputaran Persediaan}

Perputaran sediaan merupakan rasio yang digunakan untuk mengukur berapa kali dana yang ditanamkan dalam sediaan ini berputar dalam suatu periode.

$$
\begin{aligned}
& \text { inventory turn over }= \\
& \frac{\text { harga pokok barang yang dijual }}{\text { persediaan Rata-Rata }}=\ldots \text {...kali }
\end{aligned}
$$

$$
\begin{aligned}
& \text { persediaan Rata }- \text { Rata } \\
& =\frac{\text { persediaan tahun pertama }+ \text { persediaan tahun kedua }}{2}
\end{aligned}
$$

\section{METODE PENELITIAN}

Penelitian ini bersifat "Diskriptif Kuantitatif" karena data yang dianalisis merupakan data yang berupa angka-angka dan penelitian ini menggunakan skala ukur rasio. Dalam penelitian ini menggunakan butir penelitian rasio Likuiditas (current ratio), Rasio Rentabilitas (ROI, Net Profit 
JURNAL MANAJEMEN VOL. 5 NO. 2 DESEMBER 2015

Margin, Turnover Of Operating Asse)t rasio Aktivitas (Perputaran Kas,

\section{HASIL DAN PEMBAHASAN}

\section{a. Net Profit Margin}

Net Profit Margin dari tahun 2010 ke tahun 2011 mengalami penurunan, hal ini di sebabkan laba bersih dan penjualan mengalami penurunan, Tetapi 4 tahun pegamatan cenderung berfluktuasi naik dan sebaiknya dipertahankan atau dinaikan, jadi Tarawangsa Wood Instrument pada 4 tahun terakhir biayanya semakin efisien.

\section{b. Turnover Of Operating Asset}

Turnover Of Operating Asset (TOA) 4 tahun pengamatan TOA terus turun karena penjualan yang terus menurun, hanya tahun 2014 mulai naik, peusahaan harus berusaha menaikan lagi penjualannya, berati Tarawangsa Wood Instrument kurang efisien dalam meggunakan Aktiva Tetapnya

\section{c. ROI}

Dari hasil perhitungan ROI diatas menunjukan adanya penurunan yang sangat signikfikan pada tahun 2011 sampai dengan 2013 namun cenderung berfluktuasi pada ROI yang rendah akibat berfluktuasinya NPM dan TOA Menurun. 2014 NPM dan TOA meninggkat dan ROI mankin cukup
Perputaran Sediaan, Perputaraan Piutang) dan Indeks efisiensi modal kerja ( IEMK) besar, peninggkatan 2014 harus dipertahankan atau lebih ditingkatkan lagi, berarti Tarawangsa Wood Instrument belum efisien dalam mengelola biaya dan aktivanya.

\section{d. Current Ratio}

Dari perhitungkan Current Ratio Tarawangsa Wood Instrument bergerak fluktuatif dengan 4 tahun terakhir mengalami kenaikan, namun tahun 2012 dan tahun 2013 CR terlalu tinggi hal ini di karenakan Aktiva lancar yang terlalu tinggi dibandingkan dengan hutang lancar. Rasio lancar yang tinggi menunjukan kelebihan aktiva lancar, sehingga mempunyai pengaruh yang tidak baik terhadap profitabilitas perusahaan karena biaya modal tinggi. tetapi pada tahun 2014 mengalami penurunan secara signikfikan.

\section{e. Indeks Efisiensi Modal Kerja}

Dilihat dari hasil perhitungan IEMK di atas menunjukan bahwa hanya pada tahun 2012 dan tahun 2013 mengalami penurunan yang sangat siknikfikan hal ini dikarenakan likuditas yang terlalu tinggi dibandingkan rentabilitas, berarti Tarawangsa Wood Instrument pada tahun itu belum efisien 
dalam mengelola modal kerjanya, tetapi tahun 2014 mengalami kenaikan yang cukup besar dari tahun sebelumnya berarti di tahun 2014 Tarawangsa Wood Instrument sudah lebih efisien dalam mengelola modal kerjanya.

\section{f. Perputaran Kas}

Dilihat dari perhitungan perputaran kas tahun 2010 ke tahun 2011 mengalami penurunan, hal ini dikarenakan penjualan yang terus menurun, tahun 2012 hingga tahun 2014 perputaran kas mengalami kenaikan cenderung berfluktuasi namun perputaran kas semakin meningkat. Besarnya perputaran kas sudah cukup bagus, hal ini menunjukan perusahaan sudah cukup bagus. Hal ini menunjukan bahwa perusahaan dapat menjalankan usahanya dengan lancar dan perusahaan sudah efisien dalam mengelola kasnya

\section{g. Perputaran Piutang}

Di lihat dari besarnya perhitungan perputaran piutang terjadi penurunan namun cenderung berfluktuasi pada tahun 2010 hingga 2014 karena presentase penjualan relatif lebih kecil

\section{KESIMPULAN}

Berdasarkan hasil analisis dan pembahasan pada Bab IV dapat ditarik kesimpulan bahwa Penggunaan modal dibandingkan dengan presentase kenaikan piutang rata-rata. Namun walaupun perputaran piutang menurun teapi jumlah perputaran piutang masih tinggi hal ini menunjukan bahwa modal kerja yang ditanamkan dalam piutang semakin rendah dan tentunya kondisi ini bagi perusahaan semakin baik berarti investasi pada piutang semakin baik.

\section{h. Perputaran Persediaan}

Dilihat dari perhitungan perputaran persediaan menunjukan bahwa perputaran persediaan mengalami penurunan pada tahun 2010 hingga Tahun 2013 hal ini disebabkan karena presentase HPP mengalami penurunan, pada tahun 2014 perputaran persediaan mengalami kenikan hal ini di sebabkan karena HPP mengalami kenikan yang cukup besar namun ratarata persediaan mengalami penurunan. Tetapi dari perhitungan tahun 2010 hingga tahun 2014 perputaran persediaan pada Tarawangsa Wood Intrument cukup bagus, karena apabila perputaran terlalu rendah tidak baik untuk perusahaan.

kerja (MK) dari tahun 2010-2014 bergerak secara Fluktuatif, namun hanya pada tahun 2012 dan tahun 2013 penggunaan modal kerja yang kurang efisien karena 


\section{JURNAL MANAJEMEN VOL. 5 NO. 2 DESEMBER 2015}

mengalami penurunan yang cukup besar.sedangkan pada tahun 2014 modal

\section{DAFTAR PUSTAKA}

Akmaluddin Hasibuan. 2012. Manajemen Perubahan. Yogyakarta. Penerbit Andi.

Bambang Riyanto. 1997. Dasar-Dasar Pembelanjaan Perusahaan. Yogyakarta. Penerbit BPFE.

Burhan Bungin, 2013. Metodologi Penelitian Sosoal dan Ekonomi Jakarta. Kencana Prenada Media Grup

Dwi Prastowo Darminto, dan Aji Suryo. 2005. Analisis laporan Keuangan Yogyakarta, Andi.

Fahmi Irham. 2012. Pengantar Manajemen Keuangan, Alfabeta:Bandung

Hanafi, Mahmud. M. 2013. Manajemen Keuangan. Edisi Keenam. Yogyakarta: BPFE

Kasmir, 2014. Analisis Laporan Keuangan. Jakarta.Rajawali Pers

Kurniawan Agung. 2005. Transformasi Pelayanan Publik. Yogyakarta: Pembaruan.

Kuswadi. 2007. Analisis Keekonomian Proyek, Yogyakarta andi

Mujino. Drs. MM. 2013. Analisis Rentabilitas, Likuiditas dan kerja Pada Tarawangsa Wood Instrument semankin efisien.

Solvabilitas Koperasi, Usaha Kecil dan Menengah. Di Kecamatan Berbah, Sleman Yogyakart. Yogyakarta

Nurzainab Siti.2009. Efisiensi Penggunaan Modal Kerja Pada PT Mayora Indah Tbk. FE UST: Yogyakarta.

Sartono Agus.2012 Manajemen Keuangan Teori dan aplikasi. Yogyakarta.BPFE Sawir, Agnes, 2009. Analisa Kinerja Keuangan dan Perencanaan Keauangan Perusahaan. Jakarta. PT. Gramedia Pustaka Utama.

Sutrisno 2007. Manajemen Keuangan, Konsep dan AplikasiEkonisia Kampus Fakultas Ekonomi UUI: Yogyakarta.

Sartono Agus.2000. manajemen keuangan. Yogyakarta:BPFE

Sugiyono. 2013. Metode Penelitian Kombinasi (Mixed Methods). Bandung. Anggota Ikatan Penerbit Indonesia (IKAPI).

Syamsuddin, Lukman. 2001. Manajemen Keuangan Perusahaan. Jakarta. PT. Raja Grafindo Persada. 